\title{
Preoperative diclofenac is a useful adjunct to spinal anesthesia for day-case varicose vein repair
}

\author{
[L'administration préopératoire de diclofénac complète effectivement la rachi- \\ anesthésie pour tringlage variqueux]
}

Pekka Rautoma MD PhD, Ulla Santanen MD, Harri Luurila MD PhD, Vesa Perhoniemi MD PhD, Olli Erkola MD PhD

Purpose: To examine if preoperative diclofenac $50 \mathrm{mg}$ or diazepam $10 \mathrm{mg}$ po are useful adjuncts to spinal anesthesia for daycase varicose vein repair.

Methods: Two hundred ASA physical status I-II outpatients, age 1 8-60 yr, were randomized to receive either diclofenac $50 \mathrm{mg}$ po or diazepam $10 \mathrm{mg}$ po one hour before operation in a double-blind fashion ( 100 patients in both groups). If the patient was distressed or feared the spinal puncture and requested sedation, a bolus dose of alfentanil $0.5 \mathrm{mg}$ was given iv as a rescue medication. On request, patients received diclofenac $50 \mathrm{mg}$ po and, when needed, oxycodone $0.1 \mathrm{mg} \cdot \mathrm{kg}^{-1}$ im for postoperative pain relief. They were discharged with a supply of diclofenac $50 \mathrm{mg}$ tablets and were asked to record postoperative pain using a visual analogue scale (VAS) and quantity of tablets taken.

Results: The VAS scores $( \pm S D$ ) eight hours after surgery, the next morning, and in the morning and at the end of the first and second postoperative days were $23 \pm 21,12 \pm 17,11 \pm 15,8 \pm 15$ and $8 \pm 15$ in the diclofenac group, and $24 \pm 23,12 \pm 20,10 \pm 17$, $8 \pm 16$ and $7 \pm 14$ in the diazepam group, respectively (NS). In the diclofenac and diazepam groups, $31 \%$ and $67 \%$ of the patients required postoperative diclofenac during the first eight postoperative hours $(P<0.05)$. Diazepam premedication did not alter the number of patients who required alfentanil before spinal puncture. Conclusion: Diclofenac premedication reduced the analgesic requirements during the first eight hours after varicose vein repair.

Objectif : Vérifier si l'administration préopératoire de $50 \mathrm{mg}$ de diclofénac ou de $10 \mathrm{mg}$ de diazépam po sont un complément effectif à la rachianesthésie pour un tringlage variqueux.

Méthode : On a réparti de façon aléatoire en deux groupes égaux 200 patients ambulatoires d'état physique ASA I-II, de 18 à 60 ans, qui ont reçu, soit $50 \mathrm{mg}$ po de diclofénac, soit $10 \mathrm{mg}$ po de diazépam, une heure avant l'opération et en double insu. Si le patient était angoissé ou craignait la ponction rachidienne et demandait un analgésique, un bolus iv d'appoint de 0,5 mg d'alfentanil était administré. Sur demande, les patients ont reçu 50 mg po de diclofénac et, lorsque nécessaire, $0,1 \mathrm{mg} \cdot \mathrm{kg}^{-1}$ im d'oxycodone en analgésie postopératoire. Au départ du service, les patients ont reçu des comprimés de $50 \mathrm{mg}$ de diclofénac. Ils devaient aussi noter les douleurs postopératoires, selon une échelle visuelle analogique (EVA), et la quantité de comprimés consommés.

Résultats : Les scores à l'EVA ( \pm l'écart type) ont été, huit heures après l'opération ainsi que le matin et le soir des premier et second jours postopératoires de : $23 \pm 21,12 \pm 17,11 \pm 15,8 \pm 15$ et $8 \pm 15$ dans le groupe diclofénac et $24 \pm 23,12 \pm 20,10 \pm 17,8$ \pm 16 et $7 \pm 14$ dans le groupe diazépam, respectivement (NS). Dans les groupes diclofénac et diazépam, $31 \%$ et $67 \%$ des patients ont demandé du diclofénac pendant les huit premières heures postopératoires $(P<0,05)$. La prémédication avec le diazépam n'a pas modifié le nombre de patients qui ont demandé de l'alfentanil avant la ponction rachidienne.

Conclusion : La prémédication avec le diclofénac a réduit les besoins analgésiques pendant les huit premières heures suivant un tringlage variqueux.

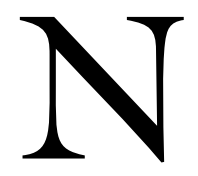

ON-STEROIDAL anti-inflammatory drugs (NSAIDs) are used commonly to reduce postoperative pain and to lessen postoperative narcotic requirements and narcotic side effects such as respiratory depression or nausea. Preoperative administration of diclofenac or ketorolac has been shown to relieve postoperative pain and to reduce postoperative analgesic requirements. ${ }^{1-6}$ Two studies have demonstrated a pre-emptive analgesic effect of diclofenac and ketorolac. ${ }^{1,4}$ However,

From the Department of Anesthesia and Intensive Care Medicine, Helsinki University Hospital, Helsinki, Finland.

Address correspondence to: Dr. Pekka Rautoma, Department of Anesthesia and Intensive Care Medicine, Malmi Hospital, Helsinki

University Hospital, Talvelantie 6, FIN-PB 650, 00029 HUS, Helsinki, Finland. Fax: +358-9-31067533;

E-mail: veli-pekka.rautoma@hus.fi

Accepted for publication March 15, 2001.

Revision accepted April 09, 2001. 
the study by Vanlersberghe et al. demonstrated no pre-emptive analgesic effect of ketorolac. ${ }^{7}$ Four other studies showed preoperative diclofenac or ketorolac to be ineffective in controlling postoperative pain. ${ }^{8-11}$

In an attempt to clarify these results, we investigated the clinical usefulness of diclofenac $50 \mathrm{mg}$ po administered one hour before day-case varicose vein repair performed under spinal anesthesia.

Materials and methods

The project received Institutional approval, and written informed consent was obtained from each patient before the operation. We studied two hundred outpatients (ASA physical status I-II, aged 18-60 yr) undergoing spinal anesthesia for elective day-case varicose vein repair. Exclusion criteria were the use of oral narcotics or prolonged therapy with non-steroidal antiinflammatory drugs, history of allergy to any study medication, patient refusal, contraindication to spinal anesthesia, and abnormal body mass index (outside 15-28). Patients with a history of bleeding disorder, gastritis or renal or liver disease were excluded.

Before the operation, each patient was instructed in the use of a $100-\mathrm{mm}$ visual analogue scale (VAS) with 0 labelled "no pain" and 100 "the worst pain imaginable". Preoperative pain was recorded on the ward, before premedication. Thereafter, pain scores were recorded eight hours after surgery, the next morning and at the end of the first and the second postoperative days. Patients were asked to record postoperative pain using the VAS and quantity of oral analgesic taken. All VAS scores were rated by the patient, not by the authors or the nurses. Patients were also asked if they had postoperative nausea, vomiting or difficulties in voiding. We provided a stamped, pre-addressed envelope to return the completed data sheets.

Patients were randomized to receive, in a doubleblind fashion, either diclofenac $50 \mathrm{mg}$ (Voltaren ${ }^{\circledR}$, Novartis Ltd) or diazepam (Diapam ${ }^{\circledR}$, Orion, Finland) one hour before spinal anesthesia. One hundred patients were included in each premedication group. After installation of routine monitors, all patients received a spinal anesthesia with $1.8 \mathrm{~mL}$ of hyperbaric bupivacaine $0.5 \%$ through a 27 gauge spinal needle with a 22 gauge introducer. We did not use local anesthesia of the skin. If the patient was distressed or feared the spinal puncture in the operating theatre and requested sedation, a bolus dose of alfentanil $0.5 \mathrm{mg}$ was given intravenously by the anesthesiologist.

Patients received diclofenac $50 \mathrm{mg}$ po for postoperative pain relief, as required. If analgesia was insufficient, patients also received $0.1 \mathrm{mg} \cdot \mathrm{kg}^{-1}$ oxycodone im. Patients were discharged home with a supply of
TABLE I Patient characteristics

\begin{tabular}{lllll}
\hline Group & Sex m/f & Age $(y r)$ & Height $(\mathrm{cm})$ & Weight $(\mathrm{kg})$ \\
\hline Diclofenac & $16 / 61$ & $43.7 \pm 12.6$ & $164 \pm 29$ & $69.2 \pm 15.7$ \\
Diazepam & $10 / 75$ & $42.7 \pm 12.6$ & $164 \pm 27$ & $67.3 \pm 14.1$ \\
\hline
\end{tabular}

There were no statistically significant differences between groups. Values are mean \pm SD.

TABLE II Requirements for preoperative alfentanil and postoperative analgesics, and incidence of side-effects ( $n=$ number of patients) during the first eight postoperative hours.

\begin{tabular}{lll}
\hline Group & Diclofenac & Diazepam \\
\hline$(n)$ & 77 & 85 \\
Alfentanil $(n)$ & 28 & 38 \\
Oxycodone $0.1 \mathrm{mg} \cdot \mathrm{kg}^{-1}(n)$ & 4 & 4 \\
Diclofenac $50 \mathrm{mg} \mathrm{one} \mathrm{tablet}(n)$ & $30^{*}$ & $57^{*}$ \\
Diclofenac $50 \mathrm{mg}$ two tablets $(n)$ & 3 & 11 \\
Postoperative nausea and vomiting $(n)$ & 11 & 10 \\
Difficulty voiding $(n)$ & 16 & 16 \\
\hline
\end{tabular}

* $P<0.05$

diclofenac $50 \mathrm{mg}$ tablets to be taken when needed, up to four tablets per $24 \mathrm{hr}$.

Statistical analysis

All randomizations were computer-generated. Data are expressed as mean \pm standard deviation $(\mathrm{SD})$. In the figure, mean \pm standard error of the mean (SEM) is used. Analysis of variance (ANOVA) was used to analyze the data, followed by Scheffe's F-test. The VAS pain scores were analyzed by a 2 -way ANOVA $(2 \times 5)$ with (1) type of premedication (diclofenac or diazepam) as the between-group factor and (2) time (eight hours postoperatively, am $1^{\text {st }}$ postoperative day, $\mathrm{pm} \mathrm{l}^{\text {st }}$ postoperative day, am $2^{\text {nd }}$ postoperative day, $\mathrm{pm} 2^{\text {nd }}$ postoperative day) as the within group factor. The chi square test was used to test the difference in the proportion of patients requesting postoperative diclofenac tablets or oxycodone. A $P$-value $\leq 0.05$ was considered statistically significant.

Results

Patient characteristics are presented in Table I.

Twelve patients were excluded from the study because they received midazolam for sedation, and four patients because general anesthesia was necessary, due to inadequate spinal anesthesia. One patient was excluded from the study because of postoperative nausea. The questionnaires were returned by $88.5 \%$ of the remaining patients. Ten patients in the diclofenac group and 11 patients in the diazepam group did not return the questionnaires (NS). Therefore, 162 patients were available for the final analysis. 
TABLE III VAS pain scores.

\begin{tabular}{llllll}
\hline Group & VAS & VAS & VAS & VAS & VAS \\
& preoperatively & $\begin{array}{l}\text { 8 hours } \\
\text { postoperatively }\end{array}$ & $\begin{array}{l}1^{\text {st }} \text { postoperative } \\
\text { day 08 a.m. }\end{array}$ & $\begin{array}{l}1^{\text {st }} \text { postoperative } \\
\text { day 08 p.m. }\end{array}$ & $\begin{array}{l}2^{\text {nd }} \text { postoperative } \\
\text { day 08 a.m. }\end{array}$ \\
\hline Diclofenac & $38 \pm 18$ & $23 \pm 21$ & $12 \pm 17$ & $11 \pm 15$ & $8 \pm 15$ \\
Diazepam & $38 \pm 26$ & $24 \pm 23$ & $12 \pm 20$ & $10 \pm 17$ & $8 \pm 15$ \\
\hline
\end{tabular}

There were no statistically significant differences between groups. Values are mean \pm SD.

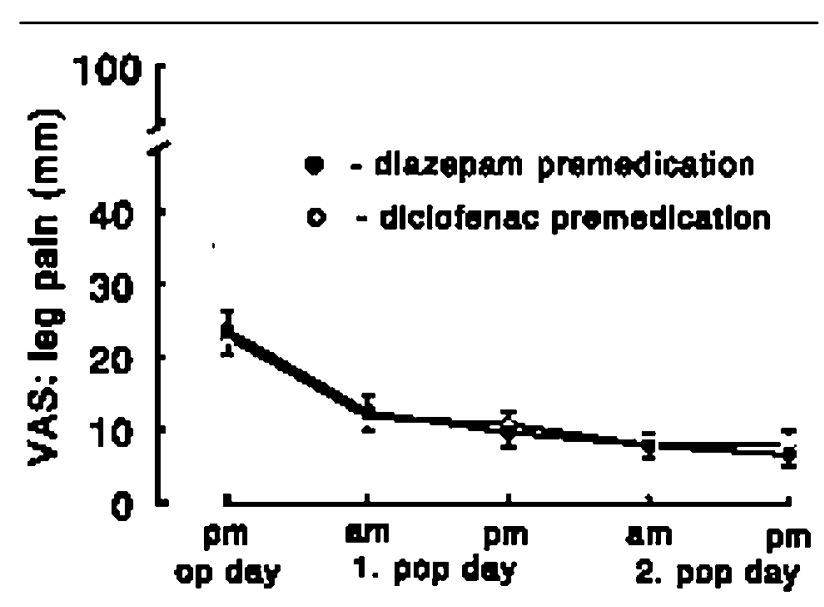

FIGURE VAS pain scores. There were no statistically significant differences between groups. Values are mean \pm SEM.

The number of patients who received alfentanil 0.5 $\mathrm{mg}$ iv for sedation is presented in Table II. Duration of surgery was $55 \pm 15(35-120)$ min (no statistical difference between the groups). Patients stayed $1.5 \pm 0.5$ hours in the recovery room where no patient needed diclofenac or oxycodone. The number of patients who received diclofenac or oxycodone during the first eight postoperative hours is presented in Table II.

There were no differences in the VAS scores of preoperative pain between the groups (Table III). The postoperative pain VAS scores did not differ between the diclofenac and diazepam groups at any time (Table III, Figure).

The number of patients who suffered from postoperative nausea and vomiting or difficulties in voiding is presented in Table II. Time to discharge after the operation was $7.7 \pm 1.5(4.5-11)$ hr (no statistical difference between the groups).

\section{Discussion}

Preoperative diclofenac reduced the need for postoperative analgesics. As expected by study design, we failed to demonstrate a decrease in postoperative VAS scores at eight hours or later in these patients undergoing day-case varicose vein repair performed under spinal anesthesia. Diazepam premedication did not alter the number of patients who required alfentanil as a rescue premedication before the spinal puncture. Finally, discharge times did not differ between groups. We did not include a group receiving placebo preoperatively because diclofenac is a potent analgesic while diazepam is not and, conversely, diazepam is a potent anxiolytic drug while diclofenac lacks such an effect. Therefore, when studying postoperative pain, the diazepam group could serve as a control group for the diclofenac group, and when studying the anxiolytic effect, the diclofenac group could serve as a control group for the diazepam group.

VAS pain scores were very low in both groups regardless of the type of premedication. This may be due to the use of spinal anesthesia, as demonstrated by Heard et al. ${ }^{12}$ In their study, patients who received spinal anesthesia had lower VAS scores than patients who had received general anesthesia. This phenomenon was irrespective of the intra-articular treatment and persisted up to $12 \mathrm{hr}$ postoperatively. ${ }^{2}$ Four studies report that protecting the nervous system from the noxious insults of surgery, using regional analgesic techniques, results in blunting of the neuroendocrine response and reduces postoperative pain. ${ }^{13-16}$ Zacharias et al. concluded in their study that preoperative use of NSAIDs may not offer a pre-emptive analgesic effect in patients who have had adequate analgesia during surgery. ${ }^{11}$

The way our study was designed, the VAS pain scores were expected to be the same in both groups (patients simply took analgesics as required to achieve pain control). The Ethics Committee did not accept a group receiving placebo for postoperative pain. Therefore, the only way to determine that preoperative diclofenac was truly effective was by demonstrating decreased analgesics requirements postoperatively.

We conclude that diazepam premedication did not reduce the number of patients who required a rescue medication for the performance of spinal puncture while diclofenac premedication reduced the need for postoperative pain medication. Diclofenac is inexpen- 
sive and causes minimal side-effects. We recommend diclofenac $50 \mathrm{mg}$ po be given one hour before surgery for suitable patients when varicose vein repair is to be performed under spinal anesthesia.

\section{References}

1 Wuolijoki E, Oikarinen VJ, Klipaavalniemi P, Hampf $G$, Tolvanen $M$. Effective postoperative pain control by preoperative injection of diclofenac. Eur J Clin Pharm 1987; 32: 249-52.

2 Nordbladh I, Oblander B, Bjorkman R Analgesia in tonsillectomy: a double-blind study on pre and postoperative treatment with diclofenac. Clin Otolaryngol 1991; 16: 554-8.

3 Gillberg LE, Harsten AS, Stabl LB. Preoperative diclofenac sodium reduces post-laparoscopy pain. Can J Anaesth 1993; 40: 406-8.

4 Parke TJ, Lowson SM, Uncles DR, Daughtery MO, Sitzman BT. Pre-emptive versus post-surgical administration of ketorolac for hysterectomy. Eur J Anaesth 1995; 12: 549-53.

5 Niemi L, Tuominen M, Pitkänen M, Rosenberg PH. Comparison of parenteral diclofenac and ketoprofen for postoperative pain relief after maxillofacial surgery. Acta Anaesthesiol Scand 1995; 39: 96-9.

6 Lin T-C, Lui M-T, Chang RC-S. Premedication with diclofenac and prednisolone to prevent postoperative pain and swelling after third molar removal. Chin Med J 1996; 58: 40-4.

7 Vanlersberghe C, Lawwers $M H$, Camu F. Preoperative ketorolac administration has no preemptive analgesic effect for minor orthopaedic surgery. Acta Anaesthesiol Scand 1996; 40: 948-52.

8 Deal SE, Pandak WM, Heuman DM. Lack of efficacy of ketorolac tromethamine for analgesia on patients undergoing colonoscopy. Am J Gastroenterol 1993; 88: 1050-3.

9 Higgins MS, Givogre JL, Marco AP, Blumenthal PD, Furman WR. Recovery from outpatient laparoscopic tubal ligation is not improved by preoperative administration of ketorolac or ibuprofen. Anesth Analg 1994; 79: 274-80.

10 Chui PT, Gin T. A comparison between ketorolac and diclofenac in laparoscopic sterilization. Eur J Anaesth 1995; 12: 597-601.

11 Zacharias M, Hunter KM, Baker AB. Effectiveness of preoperative analgesics on postoperative dental pain: a study. Anesth Prog 1996; 43: 92-6.

12 Heard SO, Edwards WT, Ferrari D, et al. Analgesic effect of intraarticular bupivacaine or morphine after arthroscopic knee surgery: a randomized, prospective, double-blind study. Anesth Analg 1992; 74: 822-6.

13 Breslow MJ, Jordan DA, Christopherson R, et al.
Epidural morphine decreases postoperative hypertension by attenuating sympathetic nervous system hyperactivity. JAMA 1989; 261: 3577-81.

14 Rutberg H, Hakanson E, Anderberg B, Jorfeldt L, Martensson J, Schildt B. Effects of the extradural administration of morphine or bupivacaine on the endocrine response to upper abdominal surgery. Br J Anaesth 1984; 56: 233-8.

15 Tverskoy M, Cozacov C, Ayche M, Bradley EL, Kissin I. Postoperative pain after inguinal herniorraphy with different types of anesthesia. Anesth Analg 1990; 70: 29-35.

16 Jebeles JA, Reilly JS, Gutierrez JF, Bradley EL, Kissin I. The effect of pre-incisional infiltration of tonsils with bupivacaine on the pain following tonsillectomy under general anesthesia. Pain 1991; 47: 305-8. 